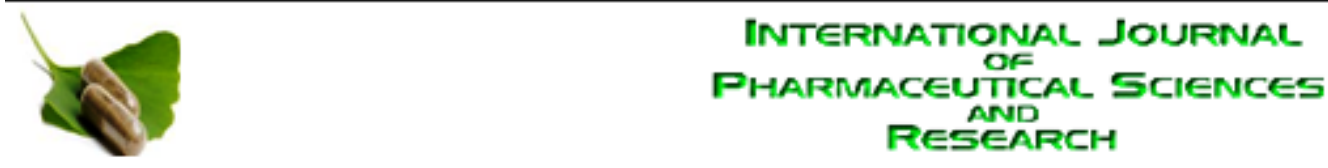

Received on 03 May, 2012; received in revised form 02 June, 2012; accepted 27 August, 2012

\title{
DEVELOPMENT AND VALIDATION OF RP-HPLC METHOD FOR SIMULTANEOUS ESTIMATION OF AMLODIPINE BESYLATE AND INDAPAMIDE IN TABLET DOSAGE FORM
}

\author{
Manish C. Raj* and Bharat G. Chaudhari
}

Department of Quality Assurance, Shree S.K. Patel College of Pharmaceutical Education and Research, Ganpat University, Ganpat Vidyanagar - 384012, Mehsana, Gujarat, India

\section{ABSTRACT}

\section{Keywords: \\ Amlodipine besylate, Indapamide, RP-HPLC, Recoveries}

Correspondence to Author:

Manish C. Raj

Department of Quality Assurance, Shree S.K. Patel College of Pharmaceutical Education and Research, Ganpat University, Ganpat Vidyanagar - 384012, Mehsana, Gujarat, India

E-mail: manish21288@gmail.com
A simple, specific, accurate and precise reversed phase high pressure liquid chromatographic method has been developed for the simultaneous determination of Amlodipine Besyltate and Indapamide in tablet dosage form by reversed phase $C_{18}$ column (Phenomenex $C_{18}, 5 \mu, 250 \mathrm{~mm} \times 4.6 \mathrm{~mm}$ ). The sample was analysed using Methanol: Water in the ratio of $95: 5$ as a mobile phase at a flow rate of $1.0 \mathrm{ml} / \mathrm{min}$ and detection at $238 \mathrm{~nm}$. Calibration curves were linear with correlation coefficient $\left(r^{2}\right) 0.996$ over a concentration range of $2-16 \mu \mathrm{g} / \mathrm{mL}$ for Amlodipine besylate and 0.997 over a concentration range of $1-7 \mu \mathrm{g} / \mathrm{mL}$ for Indapamide. The retention time for Amlodipine besylate and Indapamide was found to be 8.722 and $2.855 \mathrm{~min}$ respectively. The mean recoveries were found to be $99.98 \pm 1.40$ and 100.37 $\pm 1.25 \%$. for Amlodipine besylate and Indapamide respectively. The relative standard deviation (RSD) was found to be $<2.0 \%$ for both drugs. The proposed method was validated and successfully applied to the estimation of Amlodipine besylate and Indapamide in tablet dosage form.
INTRODUCTION: Amlodipine besylate (AMLO) is chemically 3-ethyl 5-methyl (4RS)-2-[(2 aminoethoxy) methyl]-4-(2-chlorophenyl) 6-methyl-1,4 dihydro pyridine-3, 5-dicarboxylate benzenesulphonate 1 (Figure 1), is a Calcium channel blocker, used in the treatment of hypertension ${ }^{2}$. It is official in IP, BP and USP, IP ${ }^{3}, B P{ }^{4}$ and USP ${ }^{5}$ describe HPLC method for its estimation. Literature survey reveals UV spectrophotometry ${ }^{6}$, RP-HPLC ${ }^{7}$, spectrophotometric ${ }^{8}$ method for simultaneous determination of AMLO with other drug and RP-HPLC ${ }^{9}$ method for simultaneous determination of AMLO with other drug methods for determination of AMLO in pharmaceutical dosage forms as well as in biological fluids. Indapamide (INDA) is chemically 4-Chloro- $N$-[(2RS)-2-methyl-2,3-dihydro$1 H$-indol-1-yl]-3-sulpha moylbenzamide ${ }^{10}$ (Figure 2), is a Thiazide diuretics for the treatment of hypertension ${ }^{11}$. Indapamide is official in IP ${ }^{12}, \mathrm{BP}{ }^{13}$ and USP ${ }^{14}$. IP, $B P$, and USP describe HPLC method for its estimation. Literature survey reveals LC-MS ${ }^{15}$, spectrophotometric ${ }^{16}$ and HPLC ${ }^{17}$ method for simultaneous estimation of INDA in whole human blood, RP-HPLC ${ }^{18}$ method for simultaneous estimation of INDA, LC-ESI-MS ${ }^{19}$ methods for the determination of INDA in human plasma.

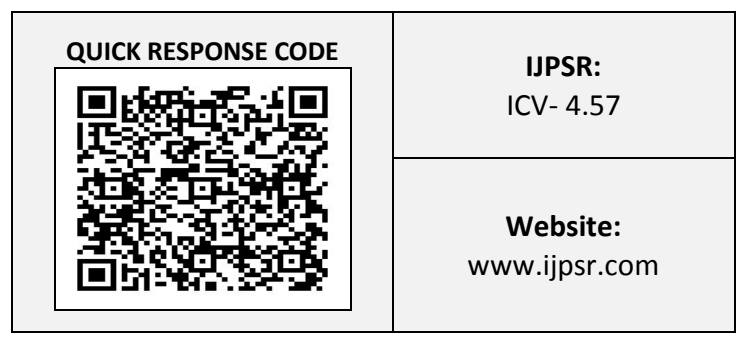


This combination is not official in any pharmacopoeia hence official and reported methods of analysis are not available for this combination. The present manuscript describes simple, sensitive, accurate, precise, rapid and economic First derivative spectrophotometric method for simultaneous estimation of AMLO and INDA in tablet dosage form.

\section{MATERIALS AND METHODS:}

Apparatus: RP-HPLC instrument equipped with a UVVisible detector and a photodiode array detector, (Shimadzu, LC-2010CHT, Japan,), manual sampler, Phenomenex C18 column $(250 \mathrm{~mm} \times 4.6 \mathrm{~mm}$ id, $5 \mu \mathrm{m}$ particle size) and LC-solution software, Analytical balance (Sartorius CP224S, Germany), Triple distillation unit consisting of borosilicate glass, Ultra sonic bath (Frontline FS 4, Mumbai, India) were used in the study.

Reagents and Materials; Amlodipine besylate (AMLO) and Indapamide (INDA) were kindly supplied as a gift samples from Torrent research center, Ahmedabad. The pharmaceutical formulation containing $5 \mathrm{mg}$ AMLO and $1.5 \mathrm{mg}$ INDA in tablet dosage form was obtained from the Serdia Pharmaceuticals Pvt. Ltd., Mumbai. HPLC grade methanol (Merck Ltd., Mumbai, India), HPLC grade acetonitrile (Finar Chemicals Ltd.,Mumbai, India). The water for RP-HPLC was prepared by triple glass distillation and filtered through a nylon $0.45 \mu \mathrm{m}-$ $47 \mathrm{~mm}$ membrane filter.

Liquid Chromatography Conditions: Chromatography conditions were obtained using Phenomenex $\mathrm{C}_{18}$ column ( $250 \mathrm{~mm} \times 4.6 \mathrm{~mm}, 5 \mu \mathrm{m}$ particle size) which were maintained at $35^{\circ} \mathrm{C}$. The analytical wavelength was set at $238 \mathrm{~nm}$ and Samples of $20 \mu \mathrm{L}$ were injected to HPLC system. The mobile phase was Methanol and Water in ratio of 95:05 (v/v) at flow rate of $1 \mathrm{ml} / \mathrm{min}$.

\section{Preparation of Solutions \& Reagents:}

Preparation of AMLO and INDA Standard Solutions: A mixed standard solution of AMLO $(100 \mu \mathrm{g} / \mathrm{ml})$ and INDA $(100 \mu \mathrm{g} / \mathrm{ml})$ was prepared by accurately weighing AMLO (10 mg) and INDA (10 mg) and dissolving in methanol and diluted to $100 \mathrm{ml}$ with methanol in the same volumetric flask. From this solutions $1 \mathrm{ml}$ were transferred in $10 \mathrm{ml}$ volumetric flask and diluted up to mark with methanol having concentration $(10 \mu \mathrm{g} / \mathrm{ml})$ for both AMLO and INDA.

Preparation of Mobile Phase: Mobile Phase was prepared by mixing of two solvents (Methanol: Water) in proportion of $(95: 5)$. All the solvents of mobile phase were filtered through nylon $0.45 \mu \mathrm{m}-47 \mathrm{~mm}$ membrane filter, degassed before use and were filled in neat and clean separate bottle.

Preparation of Sample Solution: Twenty tablets were weighed and powdered. The powder equivalent to 5 $\mathrm{mg}$ of AMLO and $1.5 \mathrm{mg}$ of INDA transferred to $50 \mathrm{ml}$ volumetric flask. Methanol ( $25 \mathrm{ml}$ ) was added to it and sonicated for $20 \mathrm{~min}$, and volume was made up to the mark with methanol. The solution was filtered through Whatman filter paper no. 41 and filtrate was suitably diluted with methanol to achieve a final concentration of $6 \mu \mathrm{g} / \mathrm{ml}$ of AMLO and $2 \mu \mathrm{g} / \mathrm{ml}$ of INDA. The absorbance of final solution was recorded at selected wavelengths for determination of AMLO and INDA. The analysis procedure was repeated three times with tablet formulation.

Determination of Analytical Wavelength: The standard solution of AMLO and INDA were injected under the chromatographic condition described above. Detection was carried out at different wavelength best response was achieved at $238 \mathrm{~nm}$ with PDA detector. So both drugs were detected at this analytical wavelength.

\section{RESULTS AND DISCUSSION:}

Method Development: To optimize the RP-HPLC parameters, several mobile phase compositions were tried. A satisfactory separation and good peak symmetry for Amlodipine besylate and Indapamide was obtained with a mobile phase methanol: Water $(95: 05 \mathrm{v} / \mathrm{v})$ at a flow rate of $1.0 \mathrm{ml} / \mathrm{min}$ to get better reproducibility and repeatability. Quantification was carried out at $238 \mathrm{~nm}$ based on peak area. Complete resolution of the peaks with clear baseline was obtained (Fig. 1) and System suitability test parameters for AMLO and INDA for the proposed method are reported in Table 1. 


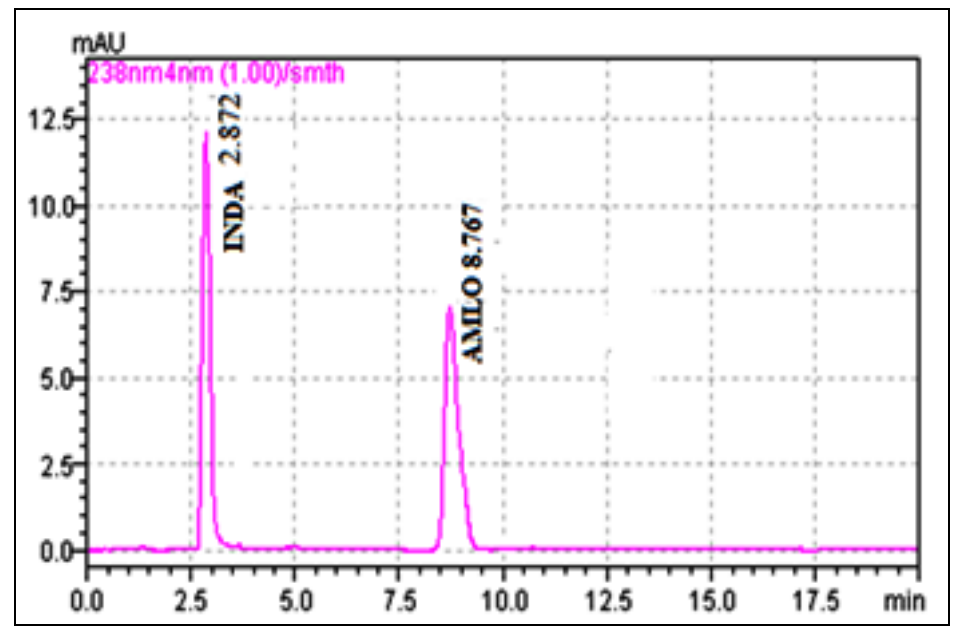

FIG. 1: CHROMATOGRAM OF STANDARD SOLUTION OF AMLO (8.767 MIN) AND INDA (2.872 MIN) AT $238 \mathrm{~nm}$

TABLE 1: SYSTEM SUITABILITY PARAMETERS OF CHROMATOGRAM FOR AMLODIPINE BESYLATE AND INDAPAMIDE

\begin{tabular}{ccc}
\hline Parameters & $\begin{array}{c}\text { AMLO } \pm \text { RSD } \\
(\mathbf{n}=\mathbf{6})\end{array}$ & $\begin{array}{c}\text { INDA } \pm \text { RSD } \\
(\mathbf{n}=\mathbf{6})\end{array}$ \\
\hline Retention time $(\mathrm{min})$ & $8.76 \pm 0.24$ & $2.87 \pm 0.29$ \\
Tailing factor & $1.27 \pm 0.34$ & $1.38 \pm 0.40$ \\
Theoretical plates & $3665.16 \pm 1.55$ & $2543.33 \pm 1.15$ \\
\cline { 2 - 3 } Resolution & \multicolumn{2}{c}{$5.76 \pm 0.42$} \\
\hline
\end{tabular}

Validation of the Proposed Method: The proposed method has been validated for the simultaneous determination of AMLO and INDA in tablet dosage form using following parameters ${ }^{20}$.

Linearity: Linear correlation was obtained between peak area Vs concentrations of AMLO and INDA in the concentration ranges of $2-16 \mu \mathrm{g} / \mathrm{ml}$ for AMLO and 1-7 $\mu \mathrm{g} / \mathrm{ml}$ for INDA. Regression parameters are mentioned in table 7.8 and the calibration curves of these two drugs at $238 \mathrm{~nm}$ are shown in Fig. 2 \& Fig. 3.

Range: Range is the interval between upper and lower concentration (amount) of analyte in sample in sample for which it has been demonstrated that the analytical method has suitable level of precision accuracy and linearity. The linear response was observed over a range of $2-16 \mu \mathrm{g} / \mathrm{ml}$ for AMLO and $1-7 \mu \mathrm{g} / \mathrm{ml}$ for INDA and the calibration curves of these two drugs at 238 $\mathrm{nm}$ are shown in Fig. 2 \& Fig. 3.

Method Precision (Repeatability): The RSD values for AMLO and INDA were found to be 0.84 and $0.79 \%$, respectively (Table 4).
The RSD values were found to be $<2 \%$, which indicates that the proposed method is repeatable.

Intermediate Precision (Reproducibility): The low $\%$ RSD values of Intraday (0.44-0.68) for AMLO and (0.38-0.65) for INDA and Interday (0.67-1.04) for AMLO and (0.61-0.74) for INDA, reveal that the proposed method is precise (Table 4).

LOD and LOQ: LOD values for AMLO and INDA were found to be $0.37 \mu \mathrm{g} / \mathrm{ml}$ and $0.14 \mu \mathrm{g} / \mathrm{ml}$, respectively and $L O Q$ values for AMLO and INDA were found to be $1.13 \mu \mathrm{g} / \mathrm{ml}$ and $0.44 \mu \mathrm{g} / \mathrm{ml}$, respectively (Table 4). These data show that the proposed method is sensitive for the determination of AMLO and INDA.

Accuracy: The recovery experiment was performed by the standard addition method. The mean recoveries obtained were $99.98 \pm 1.40 \%$ and $100.37 \pm 1.25 \%$ for AMLO and INDA, respectively. The low value of standard deviation indicates that the proposed method is accurate. Results of recovery studies are shown in Table 2.

Assay of the Pharmaceutical Formulation: The proposed validated method was successfully applied to determine AMLO and INDA in their tablet dosage form. The result obtained for AMLO and INDA was comparable with the corresponding labeled amounts (Table 3). The RP-HPLC chromatogram for AMLO and INDA in sample was recorded and is shown in Fig. 4.

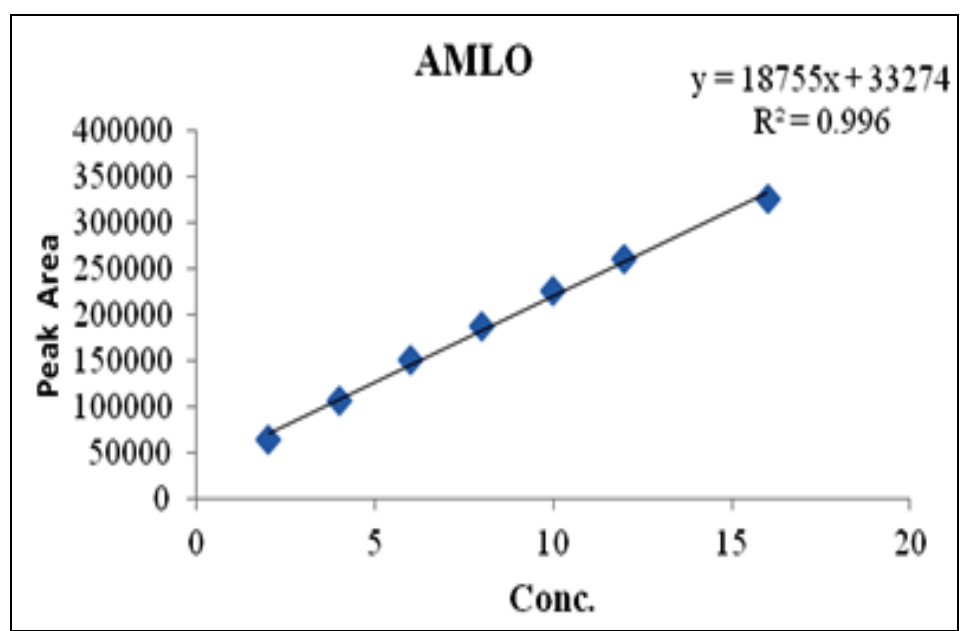

FIG. 2: CALIBRATION CURVE OF AMLO AT 238 nm 


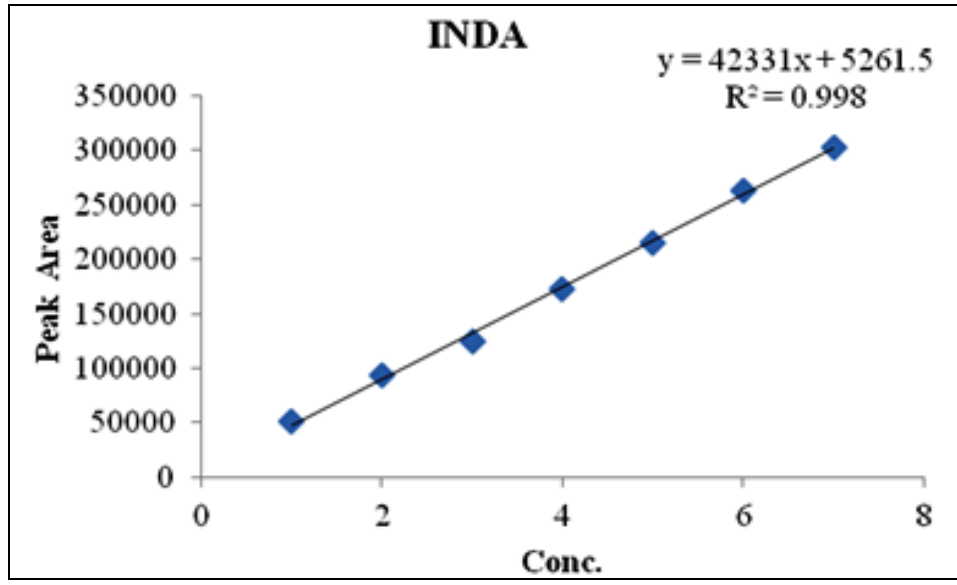

FIG. 3: CALIBRATION CURVE OF INDA AT $238 \mathrm{~nm}$

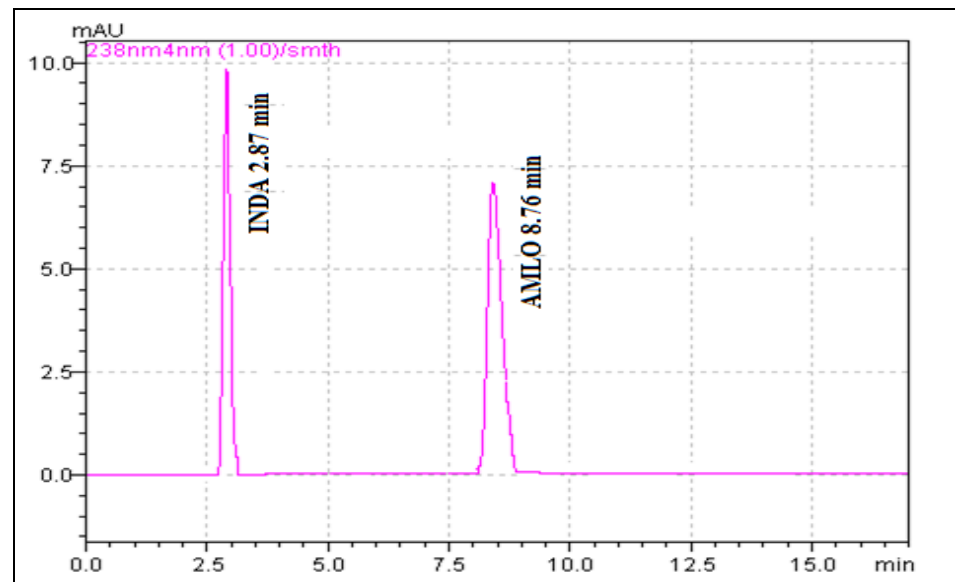

FIG. 4: CHROMATOGRAM OF SAMPLE SOLUTION OF AMLODIPINE BESYLATE (8.76 min) AND INDAPAMIDE (2.87 MIN) AT $238 \mathrm{~nm}$

TABLE 2: RECOVERY DATA FOR THE PROPOSED METHOD $(n=3)$

\begin{tabular}{|c|c|c|c|c|c|}
\hline Drug & Level & $\begin{array}{l}\text { Amount of sample taken } \\
\qquad(\mu \mathrm{g} / \mathrm{ml})\end{array}$ & $\begin{array}{l}\text { Amount of standard } \\
\text { spiked }(\mu \mathrm{g} / \mathrm{ml})\end{array}$ & $\begin{array}{l}\text { Total Amount } \\
\text { recovered ( } \mu \mathrm{g} / \mathrm{ml})\end{array}$ & $\begin{array}{c}\% \text { Mean recovery } \pm \% R S D \\
(n=3)\end{array}$ \\
\hline \multirow{3}{*}{ AMLO } & 1 & 6 & 3 & 29.85 & $99.60 \pm 1.16$ \\
\hline & II & 6 & 6 & 39.90 & $100.11 \pm 1.34$ \\
\hline & III & 6 & 9 & 50.59 & $100.25 \pm 1.69$ \\
\hline \multirow{3}{*}{ INDA } & 1 & 2 & 1 & 14.97 & $99.62 \pm 1.07$ \\
\hline & II & 2 & 2 & 19.90 & $100.85 \pm 1.12$ \\
\hline & III & 2 & 3 & 25.05 & $100.65 \pm 1.55$ \\
\hline
\end{tabular}

* Mean \% Recovery \pm RSD of Three observations.

TABLE 3: ANALYSIS OF FORMULATION OF AMLO AND INDA BY PROPOSED METHOD $(n=6)$

\begin{tabular}{ccccccc}
\hline \multirow{2}{*}{ Sample No. } & \multicolumn{2}{c}{ Label Claim } & \multicolumn{2}{c}{ Amount Found } & \multicolumn{2}{c}{ Label Claim } \\
\cline { 2 - 6 } & AMLO (mg/tab) & INDA (mg/tab) & AMLO (mg/tab) & INDA (mg/tab) & AMLO (\%) & INDA (\%) \\
\hline $\mathbf{1}$ & 5 & 1.5 & 5.08 & 1.52 & 101.66 \\
$\mathbf{2}$ & 5 & 1.5 & 4.98 & 1.49 & 99.66 \\
$\mathbf{3}$ & 5 & 1.5 & 4.97 & 1.48 & 99.50 & 99.66 \\
$\mathbf{4}$ & 5 & 1.5 & 5.04 & 1.49 & 100.83 & 98.66 \\
$\mathbf{5}$ & 5 & 1.5 & 4.98 & 1.50 & 99.66 & 99.33 \\
$\mathbf{6}$ & 5 & 1.5 & 4.98 & 1.51 & 99.66 & 100.66 \\
\hline & Mean & & 5.00 & 1.49 & 100.16 \\
& S.D. & & 0.044 & 0.014 & 0.88 \\
\hline
\end{tabular}

TABLE 4: REGRESSION ANALYSIS DATA AND SUMMARY OF VALIDATION PARAMETERS FOR THE PROPOSED METHOD

\begin{tabular}{|c|c|c|}
\hline \multirow{2}{*}{ Parameters } & \multicolumn{2}{|c|}{ RP-HPLC method } \\
\hline & AMLO & INDA \\
\hline Concentration range $(\mu \mathrm{g} / \mathrm{ml})$ & $2-16$ & $1-7$ \\
\hline Slope & 18755 & 42331 \\
\hline Intercept & 33274 & 5261 \\
\hline Correlation coefficient & 0.996 & 0.998 \\
\hline $\operatorname{LOD}(\mu \mathrm{g} / \mathrm{ml})$ & 0.37 & 0.14 \\
\hline $\mathrm{LOQ}(\mu \mathrm{g} / \mathrm{ml})$ & 1.13 & 0.44 \\
\hline Repetability (\% RSD, $n=6$ ) & 0.84 & 0.79 \\
\hline \multicolumn{3}{|l|}{ Precision (\%RSD) } \\
\hline Intraday $(n=3)$ & $0.44-0.68$ & $0.38-0.65$ \\
\hline Interday $(n=3)$ & $0.67-1.04$ & $0.61-0.74$ \\
\hline \% Recovery (Accuracy, $n=3$ ) & $99.98 \pm 1.40$ & $100.71 \pm 1.08$ \\
\hline Assay (n=6) & $100.16 \pm 0.88$ & $99.90 \pm 0.95$ \\
\hline
\end{tabular}


CONCLUSION: In this proposed method the linearity is observed in the concentration range of $2-16 \mu \mathrm{g} / \mathrm{ml}$ for Amlodipine besylate with co-efficient of correlation, $\left(r^{2}\right)=0.996$ and $1-7 \mu \mathrm{g} / \mathrm{ml}$ for Indapamide with coefficient of correlation, $\left(r^{2}\right)=0.997$ at $238 \mathrm{~nm}$. The result of the analysis of pharmaceutical formulation by the proposed method is highly reproducible and reliable and it is in good agreement with the label claim of the drug. The method can be used for the routine analysis of the Amlodipine besylate and Indapamide in combined dosage form without any interference of excipients.

ACKNOWLEDGEMENT: The authors are thankful to Torrent Research Centre, Ahmedabad, India for providing gift sample of AMLO and INDA for research. The authors are highly thankful to Shree S. K. Patel College of Pharmaceutical Education \& Research, Ganpat University, Ganpat Vidyanagar, Mehsana, Gujarat, India for providing all the facilities to carry out the work.

\section{REFERENCES:}

1. Maryadele JO Neil. The Merck Index: An Encyclopedia of chemicals, drugs and biologicals. $14^{\text {th }}$ ed. Merck Research Laboratories, Merck and Co., Inc, Whitehouse station, New Jersey 2006. p. 491.

2. Sweetman SC. Martindale: The Complete Drug Reference. $35^{\text {th }}$ ed, London, UK; Pharmaceutical Press 2007. p. 1089.

3. Indian Pharmacopeia, Vol. II. The Controller Publication, Govt of India. New Delhi 2010. p. 714.

4. British Pharmacopoeia, Vol I. The British Pharmacopoeia Commission, London 2010. P. 139.

5. The United State Pharmacopoeia, USP28-NF23, United State Pharmacopoeial Convention, Inc., Rockville MD 2009. p. 1532.

6. Patil PR and Rakesh SU. Simultaneous Estimation of Ramipril and Amlodipine By UV Spectrophotometric Method. Research Journal of Pharmacy and Technology 2009; 2(2): 304-307.

7. Prajapati J, Patel A and Patel MB. Analytical Method Development and Validation of Amlodipine Besylate and Perindopril Erbumine in combine dosage form by RP-HPLC.
International Journal of Pharmatech Research 2011; 3 (2): 801-808.

8. Chaudhari BG and Patel AB. Simultaneous Spectrophotometric Estimation of Atorvastatin Calcium and Amlodipine Besylate in Tablet dosage forms. International Journal of Chemtech Research 2010; 2 (1): 633-639.

9. Mohammdi A, Rezaour N and Hashem M. A stabilityindicating high performance liquid chromatography (HPLC) assay for the simultaneous determination of Atorvastatin and Amlodipine in commercial tablets. Journal of Chromatography B 2007; 846: 215-221.

10. Maryadele JO Neil. The Merck Index: An Encyclopedia of chemicals, drugs and biologicals. $14^{\text {th }}$ ed. Merck Research Laboratories, Merck and Co., Inc, Whitehouse station, New Jersey 2006. p. 4960.

11. S. C. Sweetman. Martindale: The Complete Drug Reference. $35^{\text {th }}$ ed., London, UK; Pharmaceutical Press 2007. p. 1180.

12. Indian Pharmacopeia, Vol. II. The Controller Publication, Govt of India. New Delhi 2010. p. 1489.

13. British Pharmacopoeia, Vol I. The British Pharmacopoeia Commission, London; 2010. p. 1099.

14. The United State Pharmacopoeia, USP28-NF23. United State Pharmacopoeial Convention, Inc., Rockville MD 2009. p. 2623.

15. Jain DS, Subbaiah G, Sanyal M, Pande UC and Shrivastav P. Liquid Chromatography - Tandom Mass Spectrometry Validated Method for Estimation of Indapamide in Human Whole Blood. Journal of Chromatography B 2006; 834(12): $149-54$.

16. Pawar PV, Gaikwad PD and Bankar VH. Development and Validation of UV-Spectrophotometric Method for the Simultaneous estimation of Atenolol and Indapamide in Bulk and Tablet dosage form. International Journal of Pharmacy and Technology 2010; 2(4): 876-885.

17. A. Radi. Stripping Voltammetric Determination of Indapamide in Serum at Castor Oil - Based Carbon Paste Electrodes. Journal of Pharm Biomed Analysis 2001; 24 (3): 413-419.

18. Miller RB, Dadgar D and Lalande M. High - performance Liquid Chromatographic Method for Determination of Indapamide in Human Whole Blood. Journal of Chromatography B 1993; 614 (2): 293-308.

19. Ding L, Yang L, Liu F, Ju W, Xiong N. A sensitive LC-ESI-MS Method for the Determination of Indapamide in Human Plasma: Method and Clinical Application Journal of Pharm Biomed Anal 2006; 42 (2): 213-219.

20. ICH, Q2 (R1) Validation of Analytical Procedures. Text and Methodology, International Conference on Harmonization 2005.
How to cite this article:

Raj MC and Chaudhari BG: Development and Validation of RPHPLC Method for Simultaneous Estimation of Amlodipine Besylate and Indapamide in Tablet Dosage Form. Int J Pharm Sci Res, 2012; Vol. 3(9): 3146-3150. 